\title{
Pengembangan Media Pembelajaran IPS Sejarah Berbasis Kesenian Ambiya Untuk Meningkatkan Ketahanan Budaya Lokal
}

Arif Wahyu Hidayat, Dany Miftahul Ula

Pendidikan Sejarah dan Sosiologi, Fakultas Pendidikan Ilmu Sosial dan Humaniora, IKIP Budi Utomo Malang

Email: wahyu.arif32@gmail.com

\begin{abstract}
Abstrak: Merasuknya nilai-nilai Barat pada kalangan masyarakat merupakan ancaman bagi budaya asli yang mencitrakan lokalitas kekhasan daerah. Kesenian daerah seperti Ambiya menghadapi ancaman serius karena banyak generasi muda yang menganggapnya kuno dan tidak menarik. Gerakan pelestarian kesenian tradisional dalam bentuk multimedia perlu diterapkan dalam pembelajaran sehingga kebudayaan lokal tetap terjaga. Tujuan penelitian 1) Mengembangkan media pembelajaran interaktif berbasis kesenian ambiya untuk meningkatkan ketahanan budaya lokal, 2) Menguji efektivitas pengembagan media pembelajaran interaktif berbasis kesenian ambiya dalam meningkatkan ketahanan budaya lokal. Metode penelitian menggunakan penelitian pengembangan untuk menghasilkan video interaktif berbasis kesenian ambiya. Populasi penelitian adalah siswa kelas VII SMP Islam swasta di kabupaten Blitar dengan teknik sampel Cluster Random Sampling. Pengumpulan data menggunakan wawancara dan angket ketahanan budaya lokal. Analisis data menggunakan pendekatan kualitatif berupa saran ahli media dan Pendekatan kuantitatif yaitu Uji Normalitas, Uji Homogenitas serta Uji t. Hasil penelitian menunjukkan melalui penerapan media pembelajaran video interaktif, siswa mampu mengetahui dan memahami kebudayaan lokal yang ada di kabupaten Blitar yaitu kesenian Ambiya. Berdasarkan data angket terdapat peningkatan ketahanan budaya lokal siswa. Hal ini dikarenakan siswa mampu menyerap nilainilai yang terdapat dalam kesenian Ambiya yang dapat diaplikasikan dalam kehidupan masyarakat.
\end{abstract}

\section{Kata Kunci: Video Interaktif, Ambiya, Budaya Lokal}

Abstract: The inclusion of Western values in the community is a threat to the native culture that imaged the locality of the local specialties. Regional arts like Ambiya face a serious threat because many young people consider it old-fashioned and unattractive. The movement to preserve traditional arts in the form of multimedia needs to be applied in learning so that local culture is maintained. Research Objectives 1) Develop an interactive learning media based on ambiya arts to improve local cultural resilience, 2) Test the effectiveness of developing an interactive learning media based on ambiya arts in increasing the resilience of local culture. The research method uses development research to produce interactive videos based on ambiya art. The study population was grade VII students of private Islamic junior high schools in Blitar district using the Cluster Random Sampling technique. Data collection uses interviews and questionnaires on local cultural resilience. Data analysis uses a qualitative approach in the form of media expert advice and a quantitative approach that is the Normality Test, Homogeneity Test and $t$ Test. The results showed that through the application of interactive video learning media, students were able to know and understand the local culture in Blitar, namely the Ambiya art. Based on the questionnaire data there was an increase in the resilience of the local culture of students. This is because students are able to absorb the values contained in Ambiya art that can be applied in people's lives.

\section{Keywords: Interactive Video, Ambiya, Local Cultural}

Pendahuluan

Era globalisasi serta modernisasi ternyata menimbulkan dilema tersendiri bagi manusia. Hal ini dapat terlihat dari sikap manusia yang tidak bisa hidup secara serba manual. Disisi lain modernisasi dan 
globalisasi menimbulkan dampak dan pengaruh yang luar biasa yaitu terus tergerusnya nilai-nilai budaya yang menjadi ciri khas dari suatu bangsa. Tidak terkecuali Indonesia, dimana modernisasi serta globalisasi telah mewabah sampai ke penjuru bangsa ini (Ruslan, 2015). Fenomena seperti narkoba, free sex, hedonisme serta sekulerisme telah mewabah dan mengikis nilai-nilai budaya lokal di Indonesia.

Kemajuan ilmu pengetahuan dan teknologi yang disertai dengan semakin berkembangnya arus globalisasi dunia membawa dampak tersendiri bagi dunia pendidikan. Banyak sekolah di Indonesia dalam beberapa tahun belakangan ini mulai melakukan globaisasi dalam sistem pendidikan internal di sekolah. Hal ini terlihat pada sekolah-sekolah yang dikenal dengan bilingual school, dengan menerapkan bahasa asing seperti bahasa Inggris dan bahasa mandarin sebagai mata pelajaran wajib sekolah.

Selain itu, berbagai jenjang pendidikan mulai dari sekolah menengah hingga perguruan tinggi baik negeri maupun swasta yang membuka program kelas internasional. Globalisasi pendidikan dilakukan untuk menjawab kebutuhan pasar akan tenaga kerja berkualitas yang semakin ketat. Melalui globalisasi pendidikan diharapakan tenaga kerja Indonesia dapat bersaing di pasar dunia. Tujuan tersebut memang sangat bagus bagi kemajuan pendidikan kita, namun proses perubahan global yang didukung oleh pengetahuan dan media teknologi akan melahirkan budaya dunia yang homogen, sehingga menyebabkan hilangnya pengalaman dan pemahaman generasi muda terhadap keragaman budaya. Sebagai seorang guru harus mampu untuk menyiapkan peserta didik agar memahami bahwa teknologi di satu sisi memberikan dampak positif ataupun manfaat tetapi juga membatasi generasi muda dalam dalam mempersiapkan diri menjadi warga global.

Menurut Tilaar (2015) kearifan lokal mempunyai nilai pedagogis karena bertujuan untuk mengatur tingkah laku yang bermanfaat bagi kepentingan bersama masyarakat. Pada tatanan konkrit, realitas atas kearifan lokal belum termanifestasikan secara nyata, sehingga institusi pendidikan perlu mewadai potensi kelokalan tersebut menjadi satu materi yang cukup implementatif dan dapat dikontektualisasikan dengan seluruh mata pelajaran yang relevan (Sularso, 2016).

Kontekstualisasi pengetahuan atas budaya lokal sebagai penguatan karakter peserta didik menjadi satu hal urgen untuk dilakukan. Berdasarkan hasil observasi, peneliti menemukan beberapa permasalahan diantaranya 1) banyak siswa yang masih belum mengenal warisan budaya yang terdapat di daerah mereka seperti kesenian ambiya. 2) inovasi pembelajaran yang diterapkan oleh guru di 
sekolah masih sangat minim. 3) kurangnya sarana pembelajaran (media pembelajaran) yang dapat dipakai dalam proses belajar mengajar. Melihat fenomena diatas, perlu adanya pengembangan dalam proses belajar mengajar agar pembelajaran menjadi lebih bermakna serta mudah dipahami siswa. Pengembangan yang dimaksud dalam penelitian ini adalah pengembangan media pembelajaran, karena melalui media pembelajaran siswa akan lebih mudah memahami pesan yang disampaikan oleh guru.

Menurut Mantri (2014) peran pemuda dalam ketahanan budaya lokal sangat penting karena dengan meningkatnya kesadaran dan identitas budaya lokal diharapkan keberadaan dan kelangsungan seni tradisional tetap terjaga. Selain itu merupakan upaya menangkal penetrasi budaya asing yang tidak sesuai dengan budaya lokal sehingga dapat memperkuat ketahanan budaya lokal.

Perkembangan dan tuntutan globalisasi yang ditandai dengan kemajuan teknologi, idealnya harus disikapi sebagai momen yang baik untuk memberi ruang kreatif dan inovatif bagi revitalisasi kesenian tradisional. Gerakan pelestarian kesenian tradisional dalam bentuk multimedia perlu diterapkan dalam pembelajaran di sekolah. Video interaktif merupakan salah satu media yang dapat dipakai guru dalam proses pembelajaan. Pelestarian kesenian tradisional melalui pengembangan media pembelajaran interaktif berbasis kesenian ambiya diharapkan mampu memberikan kontribusi dan variasi dalam pembelajaran serta mampu membentuk generasi muda yang berkarakter yang tidak melupakan warisan budaya dari leluhur sehingga berimbas pada ketahanan budaya lokal.

Berdasarkan latar belakang yang telah diuraikan terdapat beberapa permasalahan, diantaranya tentang bagaimana pengembangan media pembelajaran IPS berbasis kesenian Ambiya dalam meningkatkan ketahanan budaya lokal di kabupaten Blitar. Selain itu, bagaimana efektivitas pengembangan media pembelajaran IPS berbasis kesenian Ambiya yang dikembangkan untuk meningkatkan ketahanan budaya lokal siswa SMP kelas VII di kabupaten Blitar.

\section{Metode}

Metode penelitian yang digunakan dalam penelitian ini adalah metode penelitian dan pengembangan. Pengembangan media pembelajaran IPS menggunakan model pengembangan yang diadaptasi dari Borg dan Gall (1983). Adapun langkah-langkah yang dilakukan dalam penelitian dan pengembangan ini diadaptasi dari model research and development (R\&D) (Sugiyono 2013, h. 409) dengan desain penelitian sebagai berikut. 


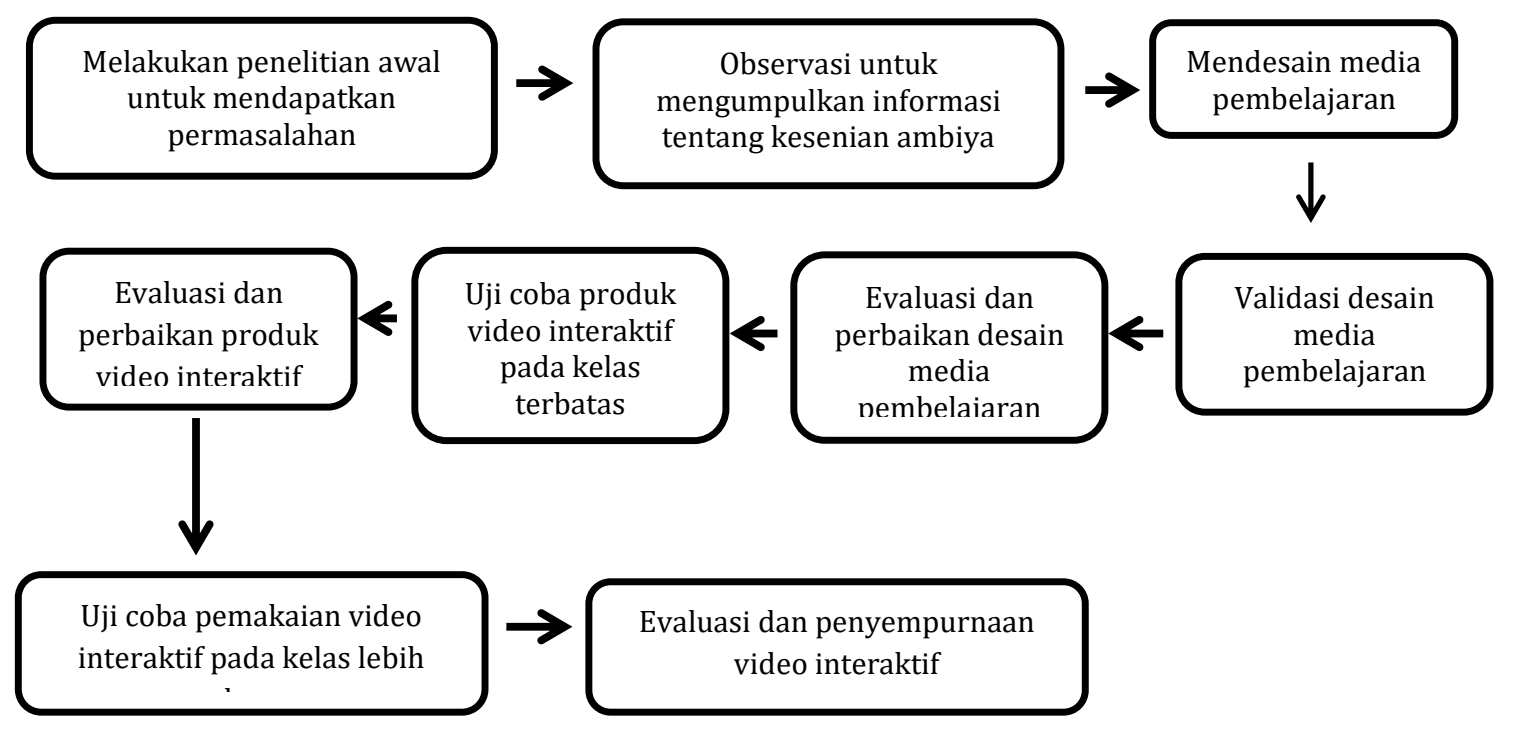

(Sugiyono, 2013)

Teknik pengumpulan data yang digunakan dalam mengumpulkan data adalah wawancara dan angket. Wawancara dilakukan untuk mengumpulkan informasi awal dalam penelitian. Wawancara dilakukan kepada kepala sekolah dan guru IPS kelas VII dengan asumsi bahwa kepala sekolah dan guru IPS tersebut lebih mengetahui kondisi serta perkembangan siswa kelas VII SMP swasta di Kabupaten Blitar. Selanjutnya, angket disusun dengan menggunakan kaidah-kaidah distribusi skor berikut ini:

Tabel 1. Skor dengan Skala Likert

\begin{tabular}{clc}
\hline No. & \multicolumn{1}{c}{ Jawaban } & Skor \\
\hline 1. & Sangat Setuju & 5 \\
2. & Setuju & 4 \\
3. & Tidak Mempuyai Pilihan & 3 \\
4. & Tidak Setuju & 2 \\
5. & Sangat Tidak Setuju & 1 \\
\hline
\end{tabular}
(Furchan, 2011)

Dalam hal ini angket ketahanan budaya lokal akan di uji cobakan kepada siswa kelas VII kelompok wajib kurikulum 2013 dan angket penilaian kelayakan media pembelajaran yang akan dibagikan kepada siswa, guru, ahli materi, dan ahli media. Lebih lanjut, data di analisis dengan menggunakan pendekatan kualitatif dan kuantitatif. Data berupa saran dan kritik dari ahli/pakar dan siswa dianalisis dengan pendekatan kualitatif. Data kelayakan media pembelajaran diolah dengan pendekatan deskriptif kualitatif.

Uji normalitas dilakukan untuk mengetahui apakah populasi berdistribusi normal. Uji normalitas menggunakan program SPSS 20 yaitu uji Kolmogorov Smornov. Lalu uji homogenitas dengan program SPSS 20 untuk uji Test of Homogeneity of Variances. Sedangkan uji $\mathrm{t}$ dilakukan dengan bantuan program SPSS 20 dengan uji Independent Samples Test.

\section{Hasil Dan Pembahasan}

Pengembangan

media pembelajaran interaktif berbasis kesenian Ambiya disusun melalui data hasil 
wawancara dengan ketua paguyuban para anggota kesenian Ambiya. kesenian Ambiya Kabupaten Blitar dan

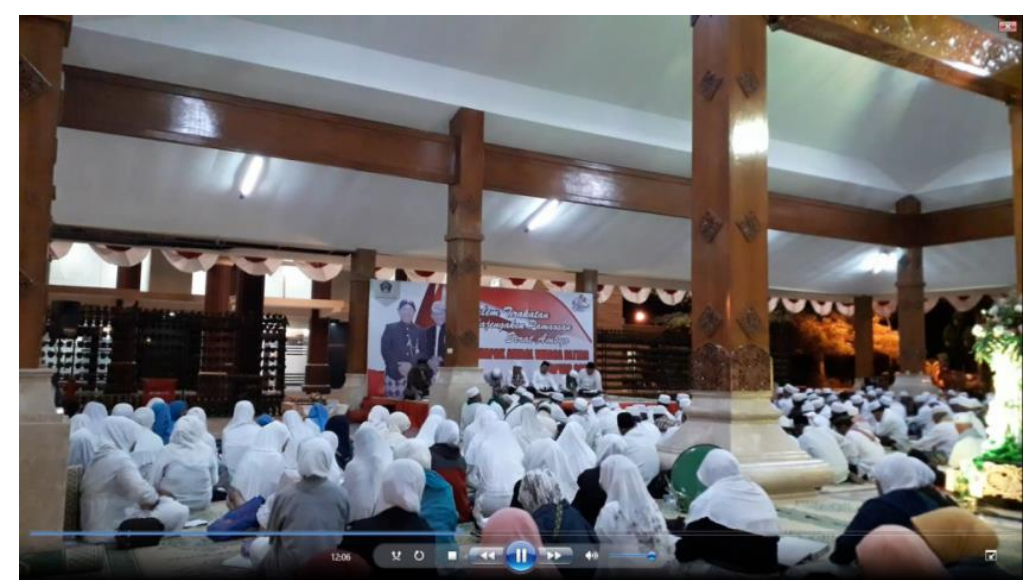

Gambar 1. Screenshot video interaktif

(Dokumen Peneliti)

Berdasarkan penilaian yang

dilakukan pada gambar 1 oleh validator

ahli didapatkan nilai rata-rata sebesar 3,5, untuk uji coba kelas terbatas diperoleh nilai rata-rata 37,5 dari 12 siswa. pada uji coba luas diperoleh nilai 37,15 dari 40 siswa, sehingga pengembangan media pembelajaran interaktif berbasis kesenian Ambiya sangat layak untuk diterapkan dalam proses belajar mengajar di sekolah.

Untuk efektifitas pengembangan media pembelajaran interaktif berbasis kesenian Ambiya untuk meningkatkan ketahanan budaya lokal sangat efektif setelah dilakukan uji normalitas, uji homogenitas dan uji hipotesis. Uji normalitas digunakan untuk mengetahui apakah data yang digunakan berdistribusi normal atau tidak. Data suatu variabel dinyatakan normal apabila uji normalitas menghasilkan probabilitas lebih besar dari 0,05 . Berdasarkan perhitungan dengan bantuan program SPSS diperoleh nilai signifikansi sebesar 0,200 untuk kelas eksperimen dan 0,079 untuk kelas kontrol. Maka dapat disimpulkan bahwa data berdistibusi normal baik kelas eksperimen maupun kelas kontrol karena masingmasing nilai signifikansi $>0,05$.

Uji homogenitas dilakukan untuk mengetahui apakah beberapa varian populasi adalah sama atau tidak. Dasar pengambilan keputusan adalah jika nilai signifikansi (sig) lebih besar dari 0,05 maka varian dari dua kelompok atau lebih adalah sama. Berdasarkan perhitungan dengan menggunakan program SPSS diperoleh nilai signifikansi (sig) sebesar 0,885 sehingga dapat disimpulkan bahwa data ketahanan budaya lokal siswa baik kelas eksperimen maupun kontrol berasal dari populasi yang homogen atau mempunyai varian yang sama. Pengujian hipotesis dalam penelitian ini menggunakan 
independent sampel t-test karena sampel yang digunakan dalam penelitian ini merupakan sampel bebas yang tidak berhubungan. Adapun hipotesis yang akan diuji dalam penelitian ini adalah efektifitas pengembangan media pembelajaran interaktif berbasis kesenian Ambiya untuk meningkatkan ketahanan budaya lokal. Berdasarkan hasil analisis perhitungan menggunakan program SPSS, diketahui bahwa $t_{\text {hit }}$ : 3,161 dengan taraf signifikansi 0,002. Karena nilai signifikansi 0,002 <0,05 maka dapat disimpulkan bahwa terdapat perbedaan antara postest kelompok eksperimen dan postest kelompok kontrol.

Berdasarkan data tersebut dapat dilihat bahwa siswa mampu memahami kebudayaan lokal yang terdapat di Kabupaten Blitar melalui penerapan media pembelajaran interaktif selain itu juga terdapat peningkatan ketahanan budaya lokal. Hal ini berbeda dengan hasil yang diperoleh kelas kontrol yang tidak dilakukan pengembangan media pembelajaran interaktif.

Menurut Seels dan Glasgow dalam Arsyad (2011) mengemukakan bahwa media interaktif merupakan sistem media penyampaian yang menyajikan materi video rekaman dengan pengendalian komputer kepada penonton yang tidak hanya mendengar dan melihat video dan suara, tetapi juga memberikan respon yang aktif dan respon itu yang menentukan kecepatan dan sekuensi penyajian. Video interaktif dirancang secara khusus sebagai media pembelajaran yang efektif dan lebih menarik minat siswa. Melalui video interaktif siswa akan merespon dari apa yang mereka lihat dan dengar sehingga pesan yang disampaikan dapat dikonstruksi oleh siswa dan menimbulkan interaksi antara siswa dengan media pembelajaran.

Penerapan media pembelajaran dalam proses pembelajaran mampu membangkitkan keinginan dan minat baru, membangkitkan motivasi dan rangsangan kegiatan belajar, bahkan membawa pengaruh-pengaruh psikologis terhadap peserta didik. Penerapan media pembelajaran dalam tahap orientasi pembelajaran akan sangat membantu keefektifan proses pembelajaran dan penyampaian pesan serta isi pembelajaran pada saat itu.

$$
\text { Menurut Smaldino }
$$

karakteristik video dalam pembelajaran terbagi menjadi beberapa tingkatan ranah pada siswa:

1. Ranah Kognitif

Dalam ranah kognitif, para pemelajar mengamati teks ulang dramatis dari dari kejadian bersejarah dan perekaman aktual dari kejadian yang lebih belakangan. Warna, suara, dan gerakan mampu menghidupkan kepribadian. Video bisa membantu buku cetak dengan memperlihatkan proses, hubungan dan teknik. 
2. Ranah Afektif

Ketika terdapat salah satu unsur dari emosi atau keinginan untuk belajar afektif, video biasanya bekerja dengan baik. Model peran dan pesan dramatis pada video bisa mempengaruhi sikap, karena potensinya yang besar untuk dampak emosional, video bisa bermanfaat dalam membentuk sikap personal dan sosial.

3. Ranah Kemampuan Motorik

Video sangat hebat untuk menampilkan bagaimana sesuatu bekerja dengan detail dan spesifik. Pertunjukan kemampuan motorik bisa dengan mudah dilihat melalui media ketimbang dalam kehidupan nyata.

4. Ranah Kemampuan interpersonal

Dengan melihat video secara bersama-sama, berbagai kelompok pemelajar yang beragam bisa membangun kesamaan pengalaman sebagai katalis untuk diskusi. Sketsasketsa bermain peran bisa dianalisis untuk menentukan apa yang telah terjadi dan untuk meminta para pemelajar menelaah apa yang seharusnya mereka lakukan selanjutnya.

Berdasarkan data yang diperoleh, siswa sangat antusias dan tertarik untuk menyimak video interaktif ini, selain itu siswa juga mampu memahami pesan yang terkandung dalam media tersebut. Penerapan media video dalam pembelajaran IPS di SMP dapat menggali daya imajinasi siswa, sehingga pemahaman siswa terhadap materi pelajaran yang disampaikan dapat terserap dengan maksimal. Hal ini dikarenakan pada materi perkembangan dan proses masuknya pengaruh Islam di Indonesia serta berbagai peninggalannya, siswa yang masih bingung untuk menginterpretasikan bagaimana proses penyebaran agama Islam di Nusantara pada waktu itu dapat terbantu melalui media video interaktif ini. Hal ini dikarenakan video interaktif ini mampu menghadirkan imajinasi yang nyata dalam proses pembelajaran di kelas.

Ketahanan budaya adalah kekuatan dan keteguhan sikap suatu bangsa dalam mempertahankan budaya asli dari pengaruh asing yang mungkin dapat merusak atau membahayakan eksistensi bangsa Indonesia. Ketahanan budaya pada dasarnya merupakan sebuah upaya pelestarian dan pengembangan yang lebih dinamis melalui upaya khusus.

Upaya lebih khusus dalam pelestarian ritual adat merupakan tindakan yang lebih diorientasikan untuk meningkatkan nilai tambah sosial-kultural yaitu nilai tambah kemartabatan, nilai tambah kebanggaan, nilai tambah jati diri dan nilai tambah akal budi serta budi pekerti (Hanif, 2017). Kebudayaan menurut Koentjaraningrat dalam Meinarno (2011) adalah sebagai seluruh sistem gagasan, tindakan dan hasil karya manusia dalam rangka kehidupan masyarakat dan 
dijadikan manusia dengan belajar. Kebudayaan terlahir karena adanya tingkah laku dari masyarakat. Kebudayaan harus dipelajari melalui enkulturasi, yaitu proses sosial budaya budaya yang dipelajari dan ditransmisikan dari generasi ke generasi. Tujuannya adalah agar kebudayaan tidak terpinggirkan seiring dengan berkembangnya jaman.

Menurut Tarcott Parsons (Ruslan, 2015) jika suatu masyarakat pada suatu bangsa ingin tetap eksis dan lestari maka ada empat paradigma fungsi yang harus terus dilaksanakan oleh masyarakat yang bersangkutan, yakni Pertama, kemampuan memelihara sistem budaya yang dianut, karena budaya adalah endapan dari perilaku manusia. Budaya masyarakat itu sendiri berubah karena terjadi transformasi nilai dari masyarakat terdahulu ke masyarakat kemudian, tetapi dengan tetap memelihara nilai-nilai yang dianggap luhur, karena tanpa hal itu akan terbentuk masyarakat baru yang lain.

Kedua, kemampuan masyarakat beradaptasi dengan dunia yang berubah dengan cepat. Masyarakat yang mampu menyesuaikan diri dengan perubahan serta memanfaatkan peluang yang timbul akan menjadi unggul. Ketiga, adanya fungsi integrasi dari unsur-unsur masyarakat yang beranekaragam secara terus menerus sehingga terbentuk kekuatan sentripetal yang semakin menyatukan masyarakat tersebut. Keempat, masyarakat perlu memiliki goal attainment atau tujuan bersama yang dari masa ke masa bertransformasi karena terus menerus diperbaiki oleh dinamika masyarakatnya dan oleh para pemimpinnya. Kesenian ambiya merupakan salah satu kesenian tradisional yang berasal dari Blitar. Kesenian ini dimainkan secara berkelompok antara sepuluh sampai dua puluh orang yang diiringi dengan tabuhan rebana. Kesenian ini biasanya dilakukan pada malam hari setelah isya' dan dilakukan pada malam jum'at.

Alasan kesenian ini dilakukan pada malam jum'at. Sebagian besar orang islam percaya bahwa malam jum'at adalah malam yang penuh berkah sehingga seluruh kegiatan yang bersifat agamis akan mendapatkan banyak pahala apabila dilakukan pada malam jum'at. Biasanya kesenian ini dilakukan malam hari habis isya' sekitar jam 8 malam sampai tengah malam, namun ada juga yang sampai subuh apabila seluruh isi kitab dibaca semua. Buku atau kitab ambiya ini tebal bahkan lebih dari seribu halaman.

Pertunjukan kesenian ambiya berpedoman pada serat ambiya yaitu naskah dengan tafsir Al-Quran yang memuat tentang riwayat hidup para nabi yang ditulis dengan menggunakan huruf arab pegon. Serat ambiya ini bentuknya berupa pupuh-pupuh gending yaitu berupa cerita perjalanan para nabi atau wali yang dilagukan atau ditembangkan. Nilai-nilai 
sosial yang dapat diambil dalam kesenian ambiya ini adalah nilai religi, nilai budi pekerti, nilai historis dan nilai budaya. Nilai religi adalah konsep ketuhanan yang bersumber pada kepercayaan manusia yang bersifat suci. Kesenian ambiya merupakan kesenian yang banyak sekali mengandung unsur religi. Melalui kesenian ambiya siswa dapat mengetahui serta, memahami kisah hidup perjalanan para nabi serta para wali dalam menyebarkan agama Islam di bumi nusantara waktu itu.

Selain itu, melalui nilai religi ini dapat membentuk pribadi siswa menjadi lebih baik serta memiki akhlak yang bagus sehingga dapat diaplikasikan dalam kehidupan sehari-hari. Nilai budi pekerti adalah sebuah sikap positif dari seseorang dalam berperilaku yang bersumber dari dalam pikiran. Nilai budi pekerti yang dapat diambil dalam serat ambiya diantaranya petuah untuk saling menghormati sesama manusia. Sikap saling menghormati sangat penting untuk diterapkan dan diimplementasikan dalam kehidupan sosial bermasyarakat.

Sehingga nilai budi pekerti ini wajib untuk diajarkan kepada anak sejak dini maka akan membentuk generasi penerus yang tangguh serta tidak mudah diadu domba dengan bangsa sendiri sehingga persatuan dan kesatuan tetap terjaga. Nilai historis adalah sesuatu yang berkaitan dengan masa lalu. Melalui kesenian ambiya kita dapat memahami bagaimana asal muasal kesenian ini muncul karena sejatinya kesenian ini digunakan oleh para wali untuk melakukan dakwah penyebaran agama islam di nusantara pada sekitar abad ke-16. Kondisi masyarakat yang masih kental dengan agama Hindu-Budha serta kepercayaan dari nenek moyang membuat penyebaran agama Islam pada masa tersebut masih sulit dan mendapatkan pertentangan. Sehingga para wali menyiasati perjuangan dakwah Islam dengan cara memasukkan ajaran-ajaran Islam pada segala bidang kehidupan mereka salah satunya lewat kesenian.

Melalui kesenian ini perkembangan agama Islam di Nusantara dapat berkembang pesat. Nilai budaya adalah nilai yang sangat penting dalam kesenian Ambiya. Tembang macapat Ambiya merupakan ciri khas kebudayaan Indonesia yang mempunyai filosofis mendalam serta keindahan ketika dilantunkan. Tembang macapat Ambiya dihiasi pula dengan aneka simbol didalamnya yang harus ditafsirkan maknanya.

Kata-kata yang sederhana, mudah dipahami akan menciptakan energi matafisik dalam diri pembacanya sehingga tembang tersebut mempunyai arti dan mempengaruhi budi pekerti. Misalkan, tembang kinanthi berasal dari kata kanthi yang artinya dituntun atau menggandeng (diarahkan dan dibimbing) tentang tata cara hidup di dunia. Dalam arti lain dilatih tetang karakter yang baik misalkan adat 
istiadat, sopan santun sehingga membentuk manusia yang mempunyai budi pekerti yang baik. Selain itu, ada tembang sinom, sinom berarti pucuk yang bersemi dan tumbuh atau konoman yang berarti masa muda. Sinom merupakan gambaran masa muda yang merupakan masa pubertas, masa mulai beranjak dewasa, masa mencari ilmu dan masa-masa pencarian jati diri. Maka sebagai remaja harus pandai memilah dan memilih antara suatu hal yang baik dan yang buruk agar tidak salah langkah, tersesat dan sia-sia masa mudanya.

Melalui pengembangan media pembelajaran berbasis kesenian Ambiya, nilai-nilai dasar kultural menjadi suatu hal yang sangat penting dalam membentuk karakter peserta didik. Mereka dapat menggali pengetahuan serta wawasan tanpa harus meninggalkan dan meninggalkan akar budayanya. Apabila peserta didik mendapatkan informasi tentang kesenian Ambiya melalui media pembelajaran video interaktif maka, dirinya tidak lagi terasing dengan lingkungan dan budayanya.

Tersampaikannya nilai-nilai dasar yang bersumber dari kebudayaan lokal (kesenian Ambiya) membuat peserta didik tidak lagi malu terhadap kebudayaan lokal yang mereka miliki. Sehingga pemahaman kebudayaan lokal perlu ditanamkan sejak dini di lingkungan pendidikan. Serta unsur lokal (daerah) dapat dijadikan sebuah simbol identitas (Sahidah \& Habsari, 2018). Oleh karena pada tahap ini elemen-elemen dasar yang terdapat dalam kebudayaan lokal disemayamkan dalam diri peserta didik.

\section{Kesimpulan}

Berdasarkan hasil penelitian diperoleh kesimpulan bahwa pengembangan media pembelajaran interaktif IPS berbasis kesenian Ambiya memiliki kelayakan serta cocok untuk diterapkan pada pembelajaran IPS kelas VII terutama pada materi perkembangan dan proses masuknya pengaruh Islam di Indonesia serta berbagai peninggalannya, karena media pembelajaran ini berisi tentang proses masuk dan berkembangnya agama islam di Nusantara pada masa itu.

Guru dapat mengembangkan media pembelajaran lebih lanjut dalam proses pembelajaran IPS dengan berbagai tema yang lain terutama mengangkat topik kekhasan kesenian daerah yang dikemas dalam media pembelajaran yang lebih inovatif dan variatif.

\section{Daftar Pustaka}

Hanif, M. (2017). Kesenian Ledug Kabupaten Magetan (Studi Nilai Simbolik Dan Sumber Ketahanan Budaya). Gulawentah:Jurnal Studi Sosial, 2(2), 79. https://doi.org/10.25273/gulawen tah.v2i2.1895

Mantri, Y. M. (2014). Pelestarian Peran Pemuda dalam Pelestarian Seni Benjang Guna meningkatkan Ketahanan Budaya Daerah (Studi di 
Kecamatan Ujungberung Kota Bandung Provinsi Jawa Barat ). Ketahanan Nasional, 3, 135-140.

Priatna, C. W. (2017). Perancangan Interior Pusat Pertunjukan Kesenian Tradisional Jawa Barat di Kota Bandung. E-Proceding of Art and Design, 4(3), 1-14.

Rohidi, T. R. (2014). Pengembangan Media Pembelajaran Pendidikan Seni Budaya Berbasis Kearifan Lokal (Wayang Sebagai Sumber Gagasan). Imajinasi - Jurnal Seni, 7(1), 1-8.

Ruslan, I. (2015). Penguatan Ketahanan Budaya Dalam Menghadapi Derasnya Arus Budaya Asing. Jurnal TAPIs, 11(1), 1-19.

Sahidah, B. A., \& Habsari, N. T. (2018). Eksistensi Bati Pecel (Sejarah, Makna Simbolis Dan Potensinya Sebagai Ikon Pariwisata Kota Madiun). Agastya: Jurnal Sejarah Dan Pembelajarannya, 8(2), 221238.http://doi.org/10.25273/ajsp.v $8 \mathrm{i} 2.2680$

Sularso. (2016). Revitalisasi Kearifan Lokal dalam Pendidikan Dasar. Jurnal Pendidikan Sekolah Dasar, 2(1), 7379.

Tresnawati, D., \& Nugraha, T. S. (2015). Pengembangan Aplikasi Pengenalan Kesenian Daerah. Jurnal Algoritma, 12(1), 1-10.ah. Kompas.

Akdon, R. (2007). Rumus dan Data dalam Aplikasi Statistika. Bandung: Alfabeta.

Arsyad, A. (2011). Media pembelajaran. Jakarta: Raja Grafindo Persada Citra Etnika

Furchan, A. (2004). Pengantar penelitian dalam pendidikan. Yogyakarta: Pustaka Pelajar.

Makmur, K. (n.d.). Ade. 2014."Pemikiran dan Wacana Ketahanan Budaya." Ketahanan Budaya: Pemikiran Dan Wacana. Ade Makmur and Sugih Biantoro (Ed). Jakarta: Pusat
Penelitian Dan Pengembangan Kebudayaan.

Meinarno, E. A., Widianto, B., \& Halida, R. (2011). Manusia dalam Kebudayaan dan Masyarakat. Jakarta: Salemba Humanika.

Riyana, C. (2007). Pedoman pengembangan media video. Jakarta: P3ai Upi.

Smaldino, S. E. (n.d.). dkk. 2011. Teknologi Pembelajaran Dan Media Untuk Belajar (Edisi 9). Jakarta: Kencana Prenada Media Group.

Sudarko.(2005). Pakeliran Padat: Pembentukan dan Penyebarannya. Surakarta:

Sugiyono, P. D. (2013). Metode penelitian manajemen. Bandung: Alfabeta, $C V$.

Tilaar, H. A. R. (2015). Pedagogik teoretis untuk Indonesia. Penerbit Buku Kompas. 